\title{
Retrospective Evaluation of 14 Patients with Bone and Joint Tuberculosis in Mersin, Turkey
}

\section{Kemik-Eklem Tüberkülozlu 14 Olgunun Retrospektif Olarak Deg̃erlendirilmesi, Mersin, Türkiye}

\author{
Gönül ASLAN'(IID), Nurbanu KURNAZ'(IID), Mahmut ÜLGER(ID), irfan $\operatorname{AYAN}^{3}(\mathrm{IID})$, Sermin TOK UMAY'(IID), \\ İclal GÜRSES ${ }^{5}$ (ID)
}

\footnotetext{
${ }^{1}$ Department of Medical Microbiology, Faculty of Medicine, University of Mersin, Mersin, Turkey

${ }^{2}$ Department of Pharmaceutical Microbiology, Faculty of Pharmacy, University of Mersin, Mersin, Turkey

${ }^{3}$ Department of Orthopedi and Traumatology, Faculty of Medicine, University of Mersin, Mersin, Turkey

${ }^{4}$ Department of Radiology, Faculty of Medicine, University of Mersin, Mersin, Turkey

${ }^{5}$ Department of Pathology, Faculty of Medicine, University of Mersin, Mersin, Turkey
}

Cite this article as: Aslan G, Kurnaz N, Ülger M, Ayan i, Tok Umay S, Gürses i. Retrospective evaluation of 14 patients with bone and joint tuberculosis in Mersin, Turkey. FLORA 2020;25(2):197-205.

\begin{abstract}
Introduction: Tuberculosis (TB), caused by Mycobacterium tuberculosis complex (MTC), is a granulomatous infection and can be localized in pulmonary and extrapulmonary sites. Of all TB cases, 1-3\% and of the extrapulmonary TB cases, 10-11\% is bone and joint TB. In this study we aimed to retrospectively analyze the demographical, microbiological, radiological and histopathological characteristics of the patients with suspected bone and joint TB.
\end{abstract}

Materials and Methods: Between January 2005-July 2019, 285 patients with suspected bone and joint TB were examined retrospectively. Mycobacterial culture and/or Ehrlich-Ziehl-Neelsen (EZN) positive patients were included into the study. The demographic characteristics, pathological, radiological and microbiological findings of the patients were evaluated.

Results: MTC positivity was detected in 14 of 285 cases by EZN and/or culture. Mean age of the cases was 34.85 years (min-max: 2-64 years). No physical examination findings compatible with TB were detected in the patients. Moreover, it was found that all of the cases had pain and/or movement limitation, trauma in two cases, contact story with TB in one case. Chronic granulomatous inflammations characterized with caseification necrosis were detected in 5 cases. Radiological findings of 11 cases were consistent with TB.

Conclusion: Bone-joint TB might be an important reason of chronic bone-joint pains and movement limitations. Therefore, we suggest that clinical, radiological, histopathological and microbiological findings should be evaluated together in the diagnosis of bone joint TB.

Key Words: Bone and joint tuberculosis; Mycobacterial bone infections; Diagnosis; Treatment 


\title{
öz
}

\section{Kemik-Eklem Tüberkülozlu 14 Olgunun Retrospektif Olarak Deg̃erlendirilmesi, Mersin, Türkiye}

\author{
Gönül ASLAN', Nurbanu KURNAZ', Mahmut ÜLGER², İrfan AYAN³ ${ }^{3}$ Sermin TOK UMAY ${ }^{4}$, i̇clal GÜRSES ${ }^{5}$
}

\footnotetext{
${ }^{1}$ Mersin Üniversitesi Tıp Fakültesi, Tıbbi Mikrobiyoloji Anabilim Dalı, Mersin, Türkiye

${ }^{2}$ Mersin Üniversitesi Eczacılık Fakültesi, Farmasötik Mikrobiyoloji Anabilim Dalı, Mersin, Türkiye

${ }^{3}$ Mersin Üniversitesi Tıp Fakültesi, Ortopedi ve Travmatoloji Anabilim Dall, Mersin, Türkiye

${ }^{4}$ Mersin Üniversitesi Tıp Fakültesi, Radyoloji Anabilim Dalı, Mersin, Türkiye

${ }^{5}$ Mersin Üniversitesi Tıp Fakültesi, Patoloji Anabilim Dalı, Mersin, Türkiye
}

Giriş: Tüberküloz (TB), Mycobacterium tuberculosis complex (MTC)'in neden olduğu akciğer ve akciğer dışı bölgelerde lokalize olabilen granülomatöz bir infeksiyondur. Tüm TB olgularının \%1-3'ü, akciğer dışı TB olgularının \%10'u kemik-eklem TB'sidir. Bu çalışmada kemik-eklem TB şüpheli hastaların demografik, mikrobiyolojik, radyolojik ve histopatolojik özelliklerinin retrospektif olarak değerlendirilmesi amaçlanmıştır.

Materyal ve Metod: Ocak 2005-Temmuz 2019 tarihleri arasında kemik-eklem TB şüphesi olan 285 hasta retrospektif olarak incelendi. Mikobakteriyel kültür ve/veya Ehrlich-Ziehl-Neelsen (EZN) pozitifliği olan hastalar çalışmaya dahil edildi. Hastaların demografik özellikleri, patolojik, radyolojik ve mikrobiyolojik bulguları değerlendirildi.

Bulgular: EZN ve/veya kültür ile 285 olgunun 14'ünde MTC pozitifliği tespit edilmiştir. Olguların yaş ortalaması 34.85 (min-max: 2-64) yıl idi. Olgularda TB ile uyumlu fizik muayene bulguları saptanmamıştır. Tüm olgularda ağrı ve/veya hareket kısıtılığı, iki olguda travma, bir olguda TB ile temas öyküsü tespit edilmiştir. Kazeifikasyon nekrozu ile karakterize kronik granülomatöz inflamasyon beş olguda tespit edilmiştir. On bir olgunun radyolojik bulgusu TB ile uyumlu bulunmuştur.

Sonuç: Kemik-eklem TB'si, kronik kemik-eklem ağrılarının ve hareket kısıtıı̆ı̆ının önemli bir nedeni olabilir. Bu neden ile kemik eklem TB tanısında klinik, radyolojik, histopatolojik ve mikrobiyolojik bulguların birlikte değerlendirilmesi gerektiği düşüncesindeyiz.

Anahtar Kelimeler: Kemik ve eklem tüberkülozu; Mikobakteriyel kemik infeksiyonları; Tanı; Tedavi

\section{INTRODUCTION}

Tuberculosis (TB), caused by Mycobacterium tuberculosis complex (MTC), is a granulomatous infection and an important public health problem in many parts of the world in spite of improvements in diagnosis and treatment ${ }^{[1]}$. Pulmonary $\mathrm{TB}$ is the most common infection form, but extrapulmonary tuberculosis (EPTB) has significant morbidity and mortality rates. In the world, $1-3 \%$ of all TB cases and 10\% of EPTB cases are located in bone and joint tissues. Skeletal involvement is present in approximately $10 \%$ of patients with EPTB. The spine is the most commonly affected skeleton area. Spinal TB accounts for about $50 \%$ of skeletal TB cases $^{[1,2]}$. In our country, the incidence of bone/joint TB in EPTB cases is approximately 7\%, and TB ranks third after $\mathrm{TB}$ lymphadenitis and pleural $\mathrm{TB}^{[3]}$.

Early diagnosis of $\mathrm{TB}$ and anti-TB treatment on time is very important to prevent bone dest- ruction and disability. The diagnosis of bone/joint $\mathrm{TB}$ can be difficult due to the painless/indolent nature of the disease and therefore requires a high degree of suspicion ${ }^{[4]}$. Clinical and radiologic findings of musculoskeletal TB may mimic those of many other infections and malignancy. There are no pathognomonic imaging signs ${ }^{[5]}$. The definitive diagnosis of spinal $\mathrm{TB}$ is made by microbiological and histological examination of fine needle biopsy specimens taken with computed tomography (CT). In cases with highly suggestive clinical suspicion, caseous granulomatous lesions are observed and diagnosed when acid-fast bacilli are found (sensitivity around $70 \%)^{[6]}$. In some regions around the world, microbiological diagnosis is an important problem. Bone and joint TB (BJTB) is a paucibacillary disease, so microbiological diagnosis is possible in only 10\%-30\% of cases $^{[7]}$. 
In this study, we aimed to retrospectively analyze the demographical, microbiological, radiological and histopathological characteristics of patients with BJTB.

\section{MATERIALS and METHODS}

Between January 2005 and July 2019, samples of 285 patients with suspected BJTB were examined retrospectively. Patients with Ehrlich-Ziehl-Neelsen (EZN) and/or culture positivity were included into the study group. Additionally, the patients' demographic characteristics, pathological and radiological findings, microbiologic and drug sensitivity tests results were evaluated.

A total of 285 clinical samples with suspected BJTB [bone tissue ( $\mathrm{n}=128,45 \%)$, synovial fluid $(n=99,34.7 \%)$, abscess $(n=48,16.8 \%)$ and bone marrow aspirates $(\mathrm{n}=10,3.5 \%)]$, which were referred to the Mycobacteriology Laboratory in the Department of Medical Microbiology, Faculty of Medicine, Mersin University, were routinely tested. Only one sample from each patient was included into the study. Repeated samples were excluded from the study. The clinical samples were obtained by debridement in seven cases, fine needle aspiration in five cases and knee arthrodesis in one case. Samples were homogenized and decontaminated with $\mathrm{N}$-acetyl-L-cysteine (NALC-NaOH) method, which is suggested by the Centers for Disease Control and Prevention $(\mathrm{CDC})^{[8]}$. Following homogenization and decontamination, the samples were cultured [Löwenstein-Jensen (LJ) and liquid system (BACTEC MGIT 960)] and smears were prepared. The smears were stained with EZN to reveal the presence of acid fast bacilli (ARB) ${ }^{[9]}$. In culture-positive isolates, MTC was identified as microscopic and macroscopic colony morphology, and biochemical methods [niacin accumulation, nitrate reduction, catalase activity, growth on para-nitrobenzoic acid (PNB) medium $]^{[9]}$. The susceptibility of the isolates to first-line anti-TB drugs [streptomycin (SM), isoniazid (INH), rifampicin (RIF), ethambutol (EMB)] was determined by using liquid automation systems ${ }^{[10]}$. All cases were negative for human immunodeficiency virus (HIV) co-infection.

A 64-slice CT scanner (Toshiba Aquillion 64, Toshiba Medical Systems, Tokyo, Japan) was used to perform CT examination of lumbar spine without contrast medium. With the DICOM imaging program (Vitrea; Vital Images), multiplanar reconstruction sections (MPR) were created. MRI (Optima 360, GE Healthcare, Milwaukee, USA) examination of spine, knee and hip were performed with intravenous gadolinium DTPA. In each case, the images were evaluated by one radiologist on axial, coronal and sagittal images on magnetic resonance image (MRI) or $\mathrm{CT}$.

Biopsy specimens consisting of abscess and bone tissue were examined grossly and processed by using routine histopathologic method (fixation and paraffin embedding) and then stained with Hematoxylin-Eosin. After staining, the characteristic microscopic features such as necrosis, granulomas and giant cells were examined.

\section{RESULTS}

ARB positivity was detected by EZN and/or culture in 14 of 285 (4.91\%) clinic specimens. Only one sample of each patient was included into the study and repetitive samples were excluded. Of the 14 cases, 8 (57.14\%) were females [the average age was 43.75 years (min-max: 26-64 years)], 6 (42.86\%) were males [the average age was 23 years (min-max: 2-63 years)] and mean age of the cases was 34.85 years (min-max: 2-64 years). In one case, only EZN positivity was detected, and MTC was isolated by culture (LJ and/or liquid systems) in 13 cases. Of the culture positive 13 cases, EZN positivity was detected in five clinic specimens (three abscess and two bone tissue). Additionally, two MTC isolate was resistant to INH. Four major drugs [INH, RIF, EMB, and pyrazinamide (PZA)] were administered in the first two months. Treatment with INH and RIF was continued for a further 10 months. Anti-TB drug therapy of 8 cases that had clinical and laboratory improvement was discontinued after one year. No drug side effects were observed in 11 cases during 12 months of anti-TB treatment and clinical information of four cases could not be reached after treatment.

There were ten cases of low back pain, two cases of knee pain, one case of ankle pain and one case of pain in the hips. Clinical symptoms and signs consistent with $\mathrm{TB}$ were not present 
Table 1. Clinical, microbiological, histopathological and radiological findings of 14 cases

\begin{tabular}{llc} 
Variables & Patients (n= 14) & \\
\hline Sex & & \\
$\quad$ Male & 6 & \\
Female & 8 & \\
Average age & 34.85 years (min-max: 2-64 years) & $1 / 14(7.1 \%)$ \\
Affected site location & Thoracic & $6 / 14(42.8 \%)$ \\
& Lumbar & $2 / 14(14.3 \%)$ \\
Knee & Hip & $3 / 14(21.4 \%)$ \\
Microbiological findings & Setatarsal bones & $1 / 14(7.1 \%)$ \\
& Sacral & $1 / 14(7.1 \%)$ \\
Histopathology findings & LJ/Liquid systems & $6 / 14(42.8 \%)$ \\
Radiological MRI and CT findings & Drug susceptibility testing & $13 / 14(92.8 \%)$ \\
& INH resistance & $2 / 14(14.3 \%)$ \\
& Chronic granulomatous inflammations & $5 / 14(35.7 \%)$ \\
& characterized with caseification necrosis & \\
& & \\
& Disk space involvement & $7 / 14(50 \%)$ \\
& Paraspinal and soft tissue abscess & $9 / 14(64.3 \%)$ \\
& Epidural abscess & $4 / 14(28.6 \%)$ \\
& Tenosynovitis & $2 / 14(14.3 \%)$ \\
& Osteomyelitis, spondylodiscitis, spondylitis & $8 / 14(57.1 \%)$ \\
& Bone erosion & $7 / 14(50 \%)$ \\
& Intraosseous abscess & $3 / 14(21.4 \%)$ \\
& Myositis & $1 / 14(7.1 \%)$ \\
& Joint space narrowing & $3 / 14(21.4 \%)$ \\
& Fistula & $1 / 14(7.1 \%)$ \\
\hline & & \\
& &
\end{tabular}

in the cases. Pulmonary TB coexistence was not detected in any of the cases according to chest radiographs. Moreover, it was found that all of the cases had pain and/or movement limitation, trauma in two cases, contact story with $\mathrm{TB}$ in one case (Table 1,2). Clinical symptoms and duration of these symptoms, follow-up time of anti-TB treatments are given in Table 2 .

It is evaluated that the radiological findings of the cases were in accordance with TB. Clinical, microbiological, histopathological and radiological findings are presented in detail in Table 1. Eight of the twelve patients had MRI (Figure 1,2) images and three patients had CT (Figure 3) images.

Chronic granulomatous inflammations characterized with caseification necrosis were detected in five cases (Figure 4-6).

\section{DISCUSSION}

The symptoms of BJTB infections are non-specific and their clinically course is slowly progressive, which leads to a delayed diagnosis and severe damage to bones or joints. As TB is a multi-dimensional disease, the diagnosis of BJTB requires high clinical suspicion ${ }^{[7]}$. Early diagnosis is important to prevent from destruction and disability in BJTB. It may be associated with morbidity and mortality despite appropriate medical and surgical treatment ${ }^{[1]}$.

According to our results, the rate of EZN positivity was $2.1 \%(6 / 285)$ while the culture positivity rate was $4.56 \%(13 / 285)$. Sirzai et al. have reported that EZN positivity was detected in a vertebral biopsy specimen ${ }^{[11]}$. In the case reported by Ural et al., EZN examination in synovial fluid was evaluated as negative and the diagnosis 


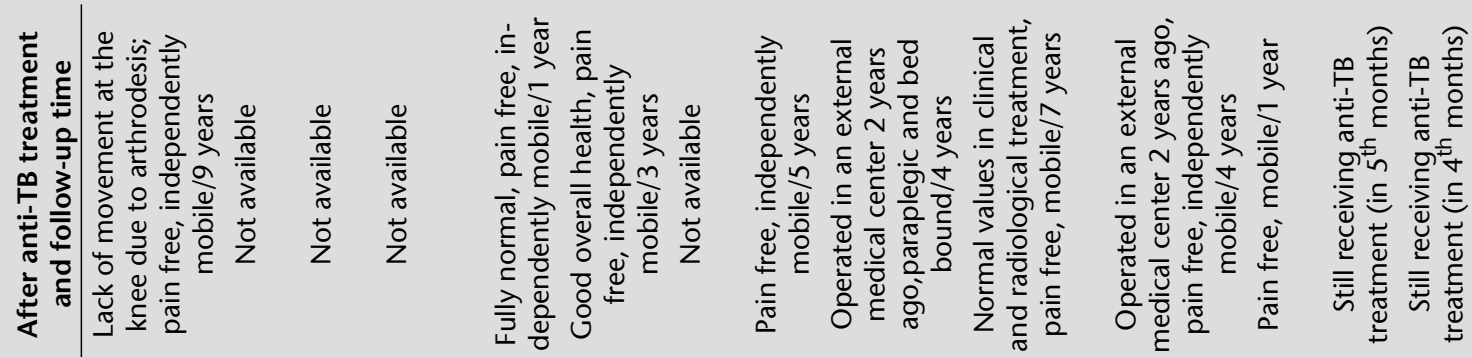

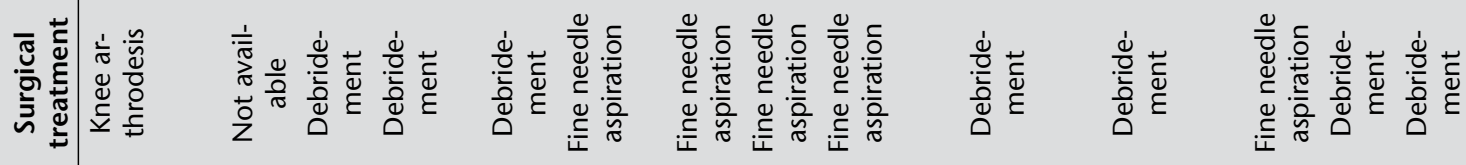

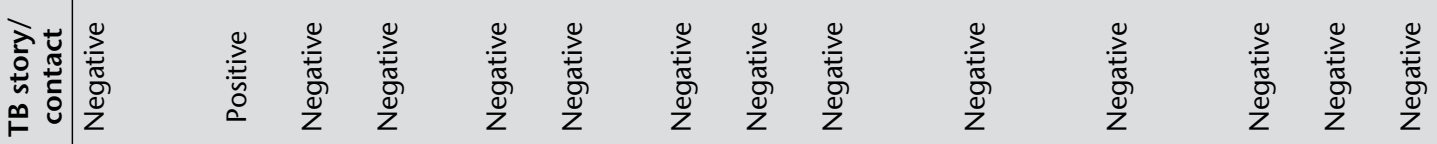

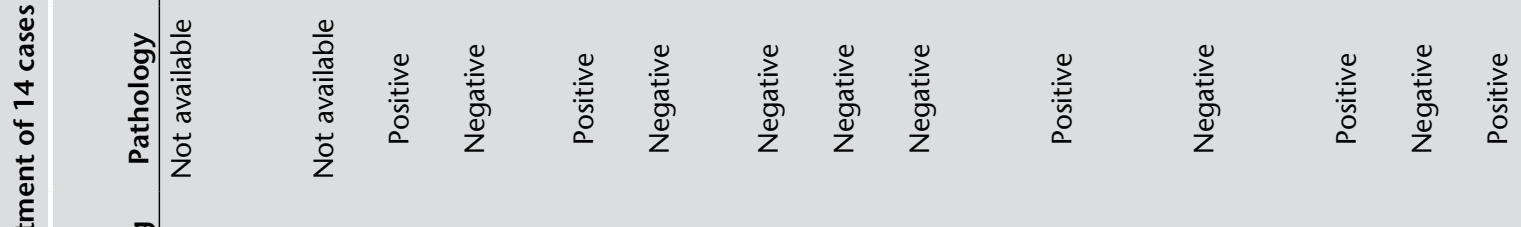

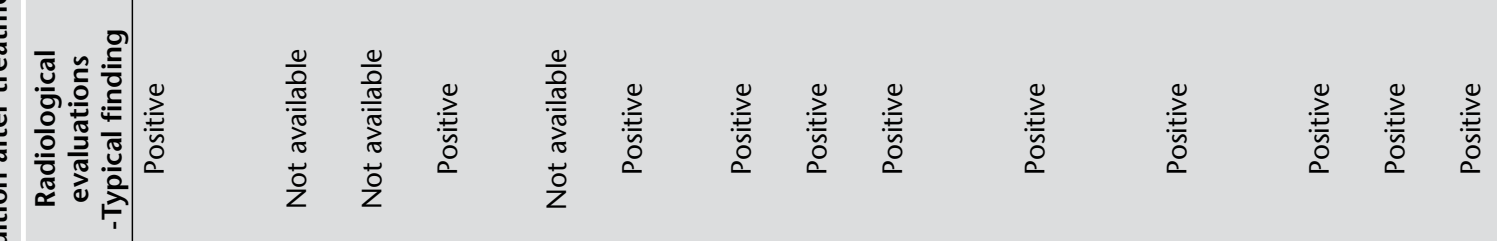

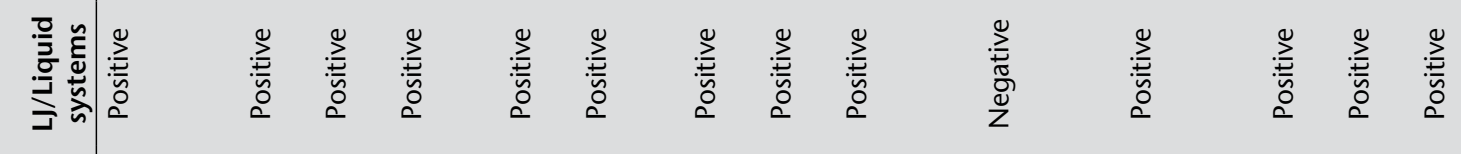

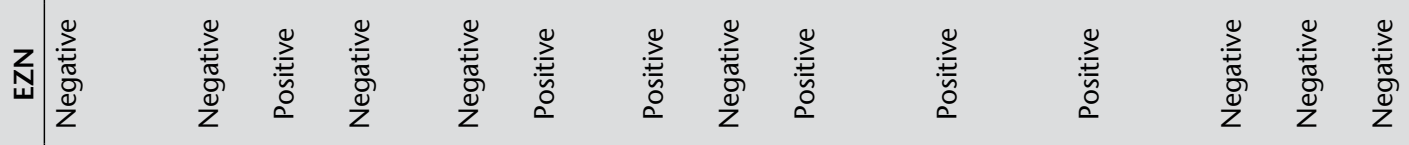
总芯离

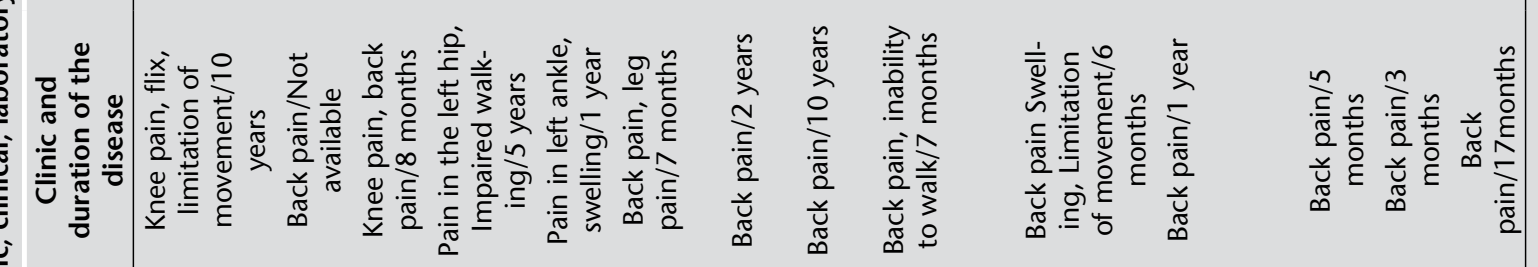

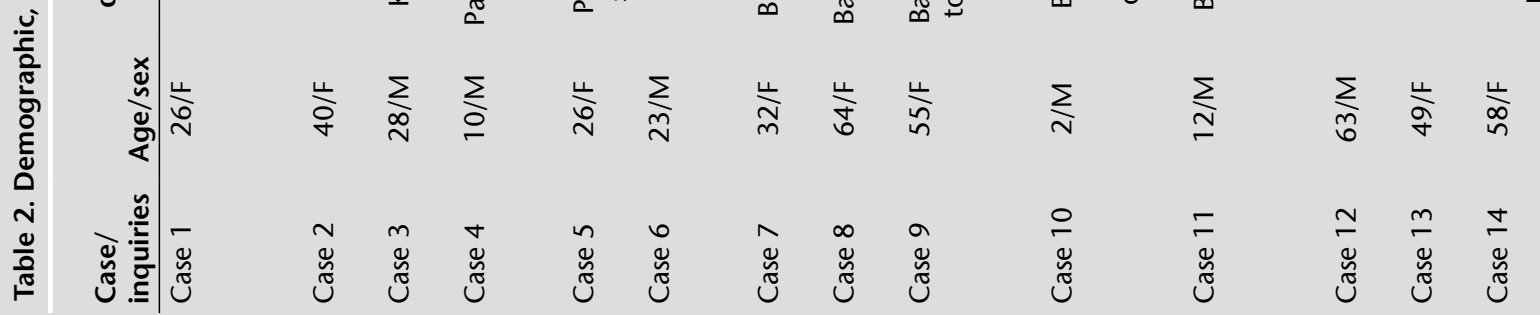




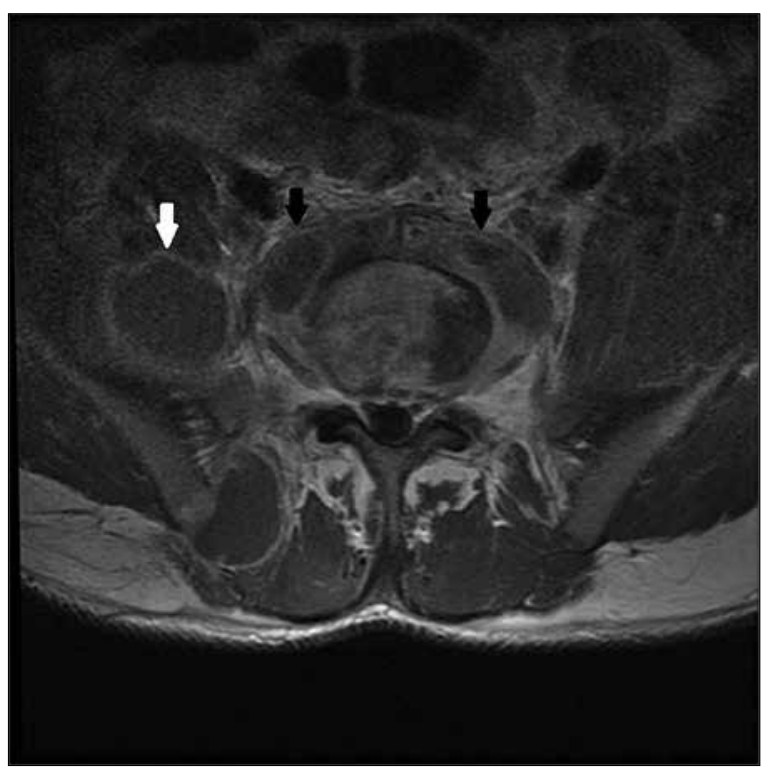

Figure 1. On enhanced T1W lumbar axial MRI, paraspinal (black arrows) and psoas muscle (white arrow) abscess (case 6).

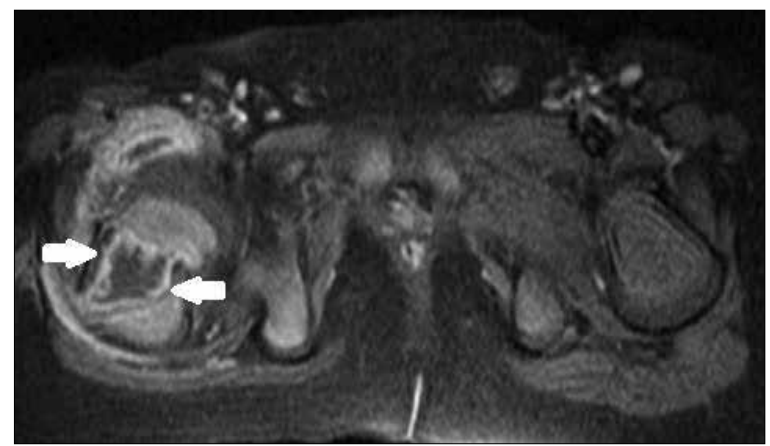

Figure 2. On enhanced hip axial MRI, intraosseos abscess in right femur head and neck (case 10).

was confirmed by culture ${ }^{[12]}$. In our TB cases, radiological findings consistent with $\mathrm{TB}$ were detected; on the other hand, the histopathological examination showed caseification necrosis characterized by chronic granulomatous inflammation only in four cases (Table 1,2).

Studies demonstrate that the incidence of BJTB varies depending on sex ${ }^{[1]}$. The study by Yoon et al. has reported that the incidence of miliary TB was $77.8 \%$ in women ${ }^{[13]}$. However, the study by Jutte and et al. has pointed to a higher incidence of BJTB, which was $51 \%$ in men ${ }^{[14]}$. The studies by Sharma et al. and by Gogia et al. have indicated a higher incidence in men, respectively as $55.4 \%$ and $63.3 \%[15,16]$.

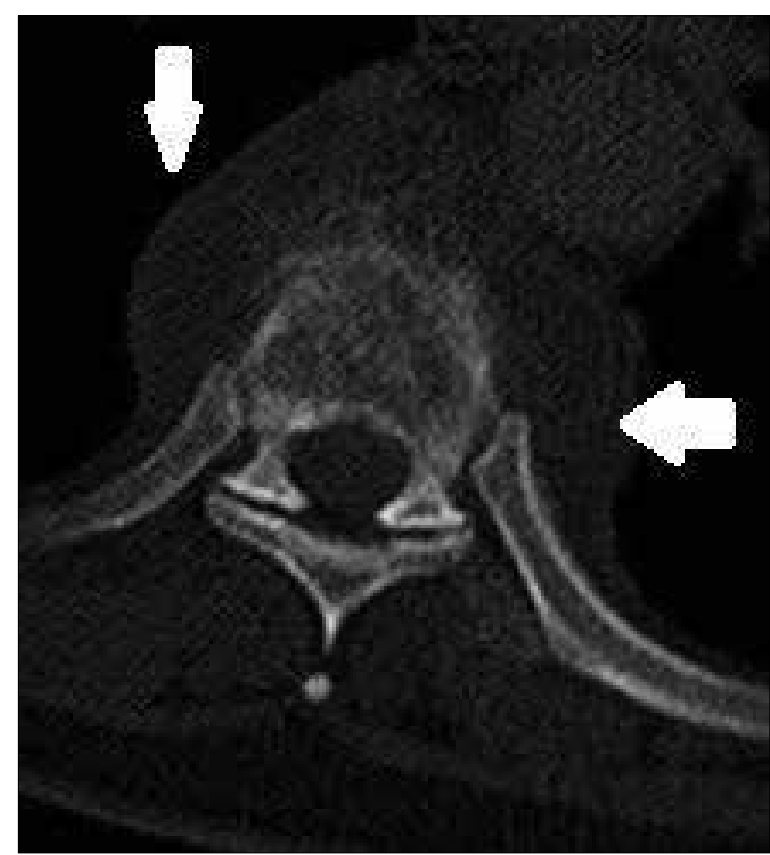

Figure 3. On lumbar CT axial imaging, soft tissue abscess (white arrow) and bone erosion (case 9).

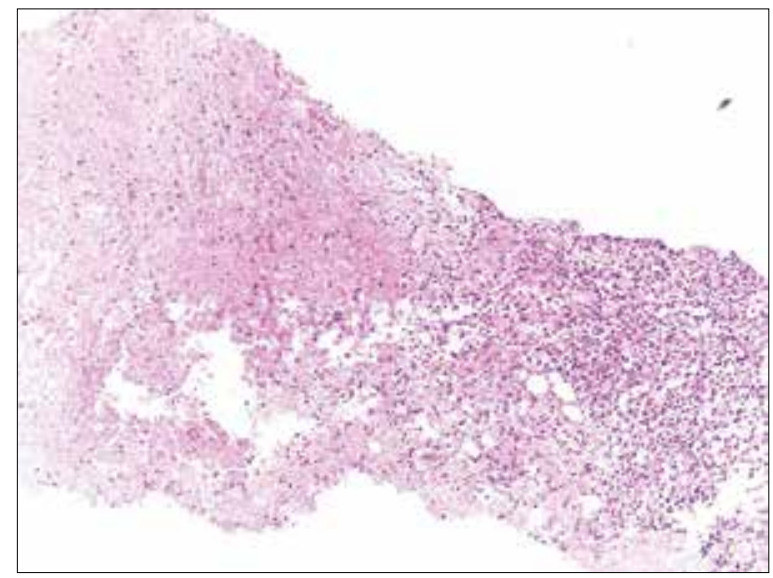

Figure 4. Necrotizing granulomatous inflammation ( $\mathrm{HE}$, $\mathrm{x} 100)$.

Contrary to other studies, we reported higher incidence in women in our study (57.1\%) (Table 2).

All age groups can suffer from BJTB ${ }^{[17]}$. The study by Shi et al. has reported a higher incidence of spinal TB among the 21-30 age groups ${ }^{[2]}$. Enache et al. have pointed to a higher incidence of BJTB among those over 40 years of age ${ }^{[18]}$. Our study revealed that the cases ranged from 2-64 years of age, with the most affected age group being 23-28 years of age $(n=4,33.3 \%)$ (Table 2). 


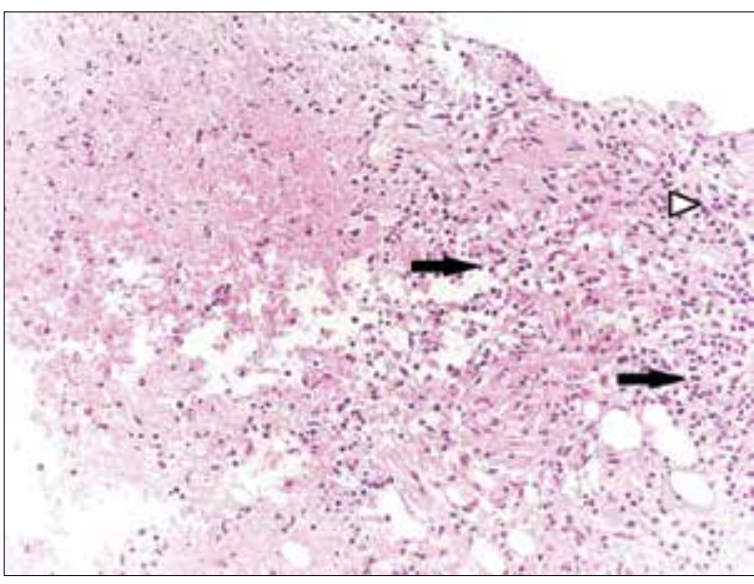

Figure 5. Microgranulomas composed of epithelioid histiocytes in the vicinity of necrosis and lymphoplasmacytic inflammatory cells are seen (HE, x100).

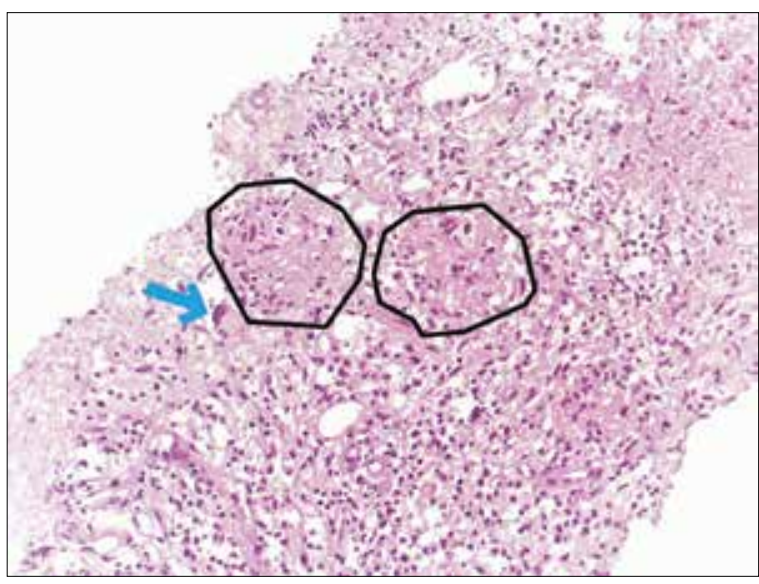

Figure 6. Microgranulomas and histiocytic giant cell (arrow) (HE, x200).

Symptoms are usually insidious in spinal TB. Despite being acute in onset, spinal TB is slowly progressive. The symptoms of diagnosis can appear two weeks to several years. Most patients (83-100\%) suffer from back pain, but only one third of them have fever ${ }^{[6]}$. The study by Arathi et al. has reported that the most common symptom was swelling and pain ${ }^{[1]}$. Shi et al. have indicated that the most common symptom was back pain, and $97.3 \%$ of the cases suffered from limitation of movement ${ }^{[2]}$. Besides, the study by Weng et al. has found out that all cases (100\%) experienced the symptom of back pain ${ }^{[19]}$. Schlesinger et al. have reported back and neck pain as the most common symptoms, which were present in $83 \%$ of the cases $^{[20]}$. The study by
Wang et al. has reported that the most common symptoms were back pain $(92.6 \%, 263$ patients), radicular pain $(15.1 \%, 43$ patients), numbness (13.7\%, 39 patients), weakness $(9.9 \%, 28$ patients) respectively ${ }^{[21]}$. The most common complaints in case reports reported from our country; Akgun et al. ${ }^{[22]}$ have reported pain, swelling and limitation of movement, Bagcier et al. ${ }^{[23]}$ have reported swelling and pain; Ural et al. ${ }^{[12]}$ have reported pain, redness and swelling. In our study, we demonstrated that the most common symptom was pain, which was present in all cases, and it was followed by back pain by $78.6 \%$ (11/14), and swelling by $14.3 \%(2 / 14)$ (Table 2).

There are commonly involved sites associated with TB in spinal region ${ }^{[24]}$. Sandhner et al. have reported thoracolumbar region as the most common site of involvement ${ }^{[17]}$. The study by Weng et al. has rindicated that the lumbar spine and thoracic spine were respectively the most commonly involved sites by $39 \%$ and $37 \%[19]$. In our study, the lumbar spine was the most commonly involved site by $42.8 \%(6 / 14)$ (Table 1).

Microbiological diagnosis of BJTB infections is difficult to make; yet, the exhibition of $\mathrm{TB}$ bacillus in the sample taken from the lesion is valuable for the diagnosis. However, the diagnosis performed through bacteriological methods may not be adequate alone $e^{[25,26]}$. The mycobacterial load in pulmonary lesions is usually $10^{7}-10^{9}$, while it is $<10^{5}$ for BJTB. Various studies have demonstrated that the incidence of positive cultu$\mathrm{re}$ is between $53-88 \%$ in $\mathrm{BJTB}^{[27-29]}$. The samples of bone tissue obtained during operation or obtained by aspiration of the infected synovium may yield a positive result if the samples contain more than 10.000 bacilli $/ \mathrm{mL}$. The confirmation of the BJTB infection by the demonstration of tubercle bacilli in lesion should be done, but this is not possible in all cases ${ }^{[19,30]}$. In our study, culture positivity was detected in 13 cases and EZN positivity was detected in 6 cases.

In patients with $\mathrm{BTJB}$, anti-TB drug therapy is recommended with INH, RIF, EMB and PZA in the initial phase, while INH and RIF are recommended in the maintenance phase of the treatment ${ }^{[31]}$. Yasa et al. have reported anti-TB treatment was completed to 12 months ${ }^{[32]}$. Ural 
et al. have reported that the first line anti-TB drug treatment was initiated for the first 2 months and then continued with INH and RIF only ${ }^{[12]}$. In our cases, a four-drug regimen was initiated for the first two months and then continued with INH and RIF for 10 months. Drug resistance in the treatment of $\mathrm{TB}$ is an important problem. The report by Weng et al. has revealed that of the $24 M$. tuberculosis isolates 75\% $(n=18)$ were susceptible to first-line anti-TB drugs (SM, INH, $\mathrm{RIF}, \mathrm{EMB}$ and pyrazinamide). INH resistance was detected in three patients, SM resistance was detected in one patient another was resistant to both INH and $\mathrm{RIF}^{[19]}$. Shi et al. have reported that the resistance ratio to INH, RIF and SM was $63.27 \%, 59.18 \%$ and $48.98 \%$ respectively ${ }^{[2]}$. In our study, two INH resistant isolates were detected.

In addition to bacteriological examination, histopathological examination is essential for bone TB. Sandher et al. have revealed that of the 71 non-caucasian patients, 25 (35\%) had positive histology and bacteriology, 15 (21\%) had positive bacteriology but non-diagnostic histology, 13 (18\%) had positive histology but negative bacteriology, and 18 (25\%) were treated on clinical suspicion as both histology and bacteriology were negative ${ }^{[17]}$. This present study found out that $33.3 \%$ of the cases in the study had both positive histopathology and bacteriology, but only $66.7 \%$ had only positive bacteriology. The study by Arathi et al. have indicated that all the cases $(n=16)$ demonstrated typical epithelioid cell granuloma, which was necrotizing in 11 cases and giant cells were present in 13 cases $^{[1]}$. This study demonstrated that necrotizing granulomatous infection and giant cells were present in five cases (Table 2). Only five cases were corrected based on histopathology findings as chronic granulomatous inflammations characterized with caseification necrosis (Figure 3-5).

TB should always be kept in mind when unusual radiographic spinal abnormalities are involved, especially in other organs, and in these cases fine needle aspiration cytology helps diagnosis. Extra-spinal bone TB generally imitation other conditions such as acute bacterial osteom- yelitis and septic arthritis and lacks typical radiological findings ${ }^{[7]}$. For that reason, bacteriological and histological methods must be employed for a fast and correct diagnosis. Typical radiological findings were present in most of the cases in this study. Indeed, radiological findings were not available only for three cases.

In the countries with high incidence of $\mathrm{TB}$, high clinical suspicion is important particularly for BJTB. A delayed diagnosis and treatment can lead to bad complications. Along with high clinical suspicion, radiological, microbiological and pathological findings are significant for the diagnosis and treatment of BJTB.

\section{CONCLUSION}

In conclusion, in the light of these findings, BJTB might be an important reason of chronic bone/joint pains and movement limitations. The evaluation of clinical, radiological, histopathological and microbiological findings in bone joint TB is important for accurate diagnosis of the disease in clinical practice. Our 14 cases, who presented with pain and movement limitation, were diagnosed as BJTB with microbiological, histopathological and radiological examinations in bone tissue and abscess samples. The majority of the cases experienced an improvement and/or regression after the anti-TB treatment. We suggest that the isolation of the bacillus and determination of anti-TB drug resistance pattern with clinical findings, radiological and histopathological methods are important for diagnosis.

\section{ETHICS COMMITTEE APPROVAL}

Ethics committee approval was not received.

\section{CONFLICT of INTEREST}

The authors declare that they have no conflict of interest.

\section{AUTHORSHIP CONTRIBUTIONS}

Concept/Design: GA, NK, MU்

Analysis/Interpretation: All of authors

Data Acquisition: All of authors

Writting: GA, NK, MÜ

Final Approval: GA 


\section{REFERENCES}

1. Arathi N, Ahmad F, Huda N. Osteoarticular tuberculosis-a three years' retrospective study. I Clin Diagn Res 2013;7(10):2189-92.

2. Shi T, Zhang Z, Dai F, Zhou Q, He Q, Luo F, et al. Retrospective study of 967 patients with spinal tuberculosis. Orthopedics 2016;39(5):838-43.

3. Turkish Ministry of Health, 2014 data. Date of access: June 9, 2017. Available from : http:/tuberkuloz.thsk.saglik.gov. tr/Publication number:1026.

4. Pandey V, Chawla K, Acharya K, Rao S, Rao S. The role of polymerase chain reaction in the management of osteoarticular tuberculosis. Int Orthop 2009;33(3):801-5.

5. Burrill J, Williams CJ, Bain G, Conder G, Hine AL, Misra RR. Tuberculosis: a radiologic review. Radiographics 2007;27:1255-73.

6. Pigrau C,Rodriguez-Pardo D. Bone and joint tuberculosis. Eur Spine 2013;22(4):556-66.

7. Garcia G, Martinez O, Rey G, Gonzalez C. Clinical, radiological and molecular diagnosis correlation in serum samples from patients with osteoarticular tuberculosis. Asian Pac J Trop Biomed 2014;4(7):581-5.

8. Soolingen DV, Jarlier V, Drobniewski F. Information for physicians: The laboratory diagnosis of tuberculosis-first steps. In: Mastering the Basics of TB Control: Development of a Handbook on TB Diagnostic Methods. Stockholm: European Centre for Disease Prevention and Control Technical Report. 2011, p. 96-99. Date of access: January 1, 2017. Available from: http://www.ecdc.europa.eu/en/publications/Publications/1105_TER_Basics_TB_control.pdf

9. Isenberg $H D(e d)$. Clinical Microbiology Procedures Handbook. Vol 2. Washington, DC: ASM Press, 2004.

10. National Committee for Clinical Laboratory Standards, Antimycobacterial susceptibility testing for Mycobacterium tuberculosis, Tentative standard M24-T, Wayne, PA; National Committee for Clinical Laboratory Standards, 1995.

11. Şirzai H, Doğu B, Demir S, Yılmaz F, Kuran B. Spinal tüberküloz. Türk Fiz Tıp Rehab Derg 2014;60:261-6.

12. Ural O, Sümer Ş, Demir NA, Çiftci Ş. Diz ekleminde gelişen tüberküloz septik artrit olgusu. FLORA 2018;23(4):218-22.

13. Yoon HJ, Song YG, Park WI, Choi JP, Chang KH, Kim JM. Clinical manifestations and diagnosis of extrapulmonary tuberculosis. Yonsei Med J 2004;45(3):453-61.

14. Jutte PC, vanLoenhout-Rooyackers JH, Borgdorff MW, van Horn IR. Increase of bone and joint tuberculosis in The Netherlands. J Bone Joint Surg Br 2004;86(6):901-4.

15. Sharma V, Anjum R, Choudhary V, SinghTP. Epidemiological pattern of osteoarticular tuberculosis in a teaching hospital of Rural India: a prospective study. Int I Biomed Res 2016;7(5):273-5.

16. Gogia KK, Shubhendu Gupta S. Osteoarticular tuberculosis - a study associated with socio demographic factors. Ann Intern Med Dental Res 2016;2(6):12-7.

17. Sandher DS, Al-jibury M, Paton RW, Ormerod LP. Bone and joint tuberculosis: cases in Blackburn between 1988 and 2005. J Bone Joint Surg Br 2007;89(10):1379-81.
18. Enache SD, Pleasea IE, Anusca D, Zaharia B, Pop OT. Osteoarticular tuberculosis-a ten years case review Rom. J Morphol Embryol 2005;46:67-72.

19. Weng $C Y$, Chi CY, Shih PJ, Ho CM, Lin PC, Chou CH, et al. Spinal tuberculosis in non-HIV-infected patients: 10 year experience of a medical center in central Taiwan. J Microbiol Immunol Infect 2010;43(6):464-9.

20. Schlesinger N, Lardizabal A, Rao J, McDonald R. Tuberculosis of the spine: experience in an inner city hospital. J Clin Rheumatol 2005;11(1):17-20.

21. Wang H, Li C, Wang J, Zhang Z, Zhou Y. Characteristics of patients with spinal tuberculosis: seven-year experience of a teaching hospital in Southwest China. Int Orthop 2012;36(7):1429-34.

22. Akgün U, Erol B, Çimşit Ç, Karahan M. Diz eklemi tüberkülozu: olgu sunumu. Acta Orthop Traumatol Turc 2007;41(5):214-8.

23. Bağcıer F, Çelik A, Melikoğlu MA. Nadir görülen kronik dirsek monoartriti: bir tüberküloz vakası. RAED Dergisi 2015;7(1):20-3

24. Garg RK, Somvanshi DS. Spinal tuberculosis: a review. J Spinal Cord Med 2011;34(5):440-54.

25. Agrawal V, Patgaonkar PR, Nagariya SP. Tuberculosis of spine. J Craniovertebr Junction Spine 2010;1(2):74-85.

26. Rasouli MR, Mirkoohi M, Vaccaro AR, Yarandi KK, Movaghar VR. Spinal tuberculosis: diagnosis and management. Asian Spine J 2012;6(4):294-308.

27. Al-Othman A, Memish ZA, Awada A, Al-Mahmood S, Al-Sadoon S, Rahman MM, et al. Tuberculous spondylitis: analysis of 69 cases from Saudi Arabia. Spine 2001;26:565-70.

28. Polley P, Dunn R. Noncontiguous spinal tuberculosis: incidence and management. Eur Spine / 2009;118:10961101.

29. Pertuiset E, Beaudreuil J, Liote F, Horusitzky A, Kemiche F, Richette $P$, et al. Spinal tuberculosis in adults. A study of 103 cases in a developed country, 1980-1994. Medicine (Baltimore) 1999;1 78(5):309-20.

30. Ramirez-Lapausa M, Menendez-Saldana, Noguerado-Asensio, A. Extrapulmonary tuberculosis: an overview. Rev Esp Sanid Penit 2015;17:3-11.

31. Eskola A, Santavirta $S$, Konttinen $Y T$, Tallroth $K$, Lindholm ST. Arthroplasty for old tuberculosis of the knee. J Bone Joint Surg $\mathrm{Br}$ 1988;70:767-9.

32. Yaşa $O$, Ergüven $M$, Demir $S$. Ender yerleșimli tüberküloz osteomyeliti ve kranial tutulumu olan millier tüberküloz vakası. Çocuk Dergisi 2012;12(2):86-9.

\section{Address for Correspondence/Yazıșma Adresi}

Prof. Dr. Gönül ASLAN

Mersin Üniversitesi Tıp Fakültesi,

Tıbbi Mikrobiyoloji Anabilim Dalı,

Mersin-Türkiye

E-mail: drgaslan@gmail.com 